\title{
Emergency knowledge in one rescue team of power network
}

\author{
MENG Fanshan ${ }^{*}$, ZHAO Yulan, DAI Dongme \\ From 2012 PLA Emergency Medicine Annual Congress \\ Beijing, China. 9-12 November 2012
}

\section{Objective}

To investigate the mastery of emergency knowledge in one rescue team of power network in Taian.

\section{Methods}

We investigated emergency knowledge in one rescue team of power network in Taian by questionnaires, which include CPR skill, hemostasis, treatment of respiratory tract obstruction, drowning, electric shock, intoxication and spinal fractures.

\section{Results}

The members of the team have a little general emergency knowledge, especially in CPR and treatment of spinal rupture, but they could not treat them properly and needed further training, and most of them would like to gain the emergency knowledge and perform it in case of emergency.

\section{Conclusion}

The rescue team of power network knew a little emergency knowledge, but they needed further training. They could be a desirable group for emergency training.

Submit your next manuscript to BioMed Central and take full advantage of:

- Convenient online submission

- Thorough peer review

- No space constraints or color figure charges

- Immediate publication on acceptance

- Inclusion in PubMed, CAS, Scopus and Google Scholar

- Research which is freely available for redistribution

\section{() Biomed Central}

\section{() Biomed Central}

